\title{
Blood glucose and outcomes in critically ill children in Brazilian Amazon: an
}

\section{observational study}

Glicemia e mortalidade na criança gravemente doente na Amazônia brasileira: estudo observacional

Glucosa en sangre y mortalidad en niños críticamente enfermos en la Amazonía brasileña: un estudio observacional

Emmerson Carlos Franco de Farias ORCID: https://orcid.org/0000-0001-8627-5694 Hospital Fundação Santa Casa de Misericórdia do Pará, Brazil

E-mail: emmersonfariasbrandynew@gmail.com

Patrícia Barbosa de Carvalho ORCID: https://orcid.org/0000-0002-6157-2083 Hospital Fundação Santa Casa de Misericórdia do Pará, Brazil E-mail:patty_assuncao2@hotmail.com

Manoel Jaime Castro Pavão Júnior ORCID: https://orcid.org/0000-0001-5685-9947 Hospital Fundação Santa Casa de Misericórdia do Pará, Brazil E-mail: manoelpavaojr@gmail.com

Luana Guimarães Dias

ORCID: https://orcid.org/0000-0002-5092-2324 Hospital Fundação Santa Casa de Misericórdia do Pará, Brazil E-mail: luanagdias@hotmail.com

Marília Cunha Botelho Alves

ORCID: https://orcid.org/0000-0002-1653-9620 Hospital Fundação Santa Casa de Misericórdia do Pará, Brazil

E-mail: mariliabotelho83@yahoo.com.br

Samuel Filipe Lopes Alves

ORCID: https://orcid.org/0000-0003-1437-5674 Universidade do Estado do Pará, Brazil E-mail: samuel.alves@aluno.uepa.br

Emanuele Rocha da Silva

ORCID: https://orcid.org/0000-0002-9109-4158 Universidade Federal do Pará, Brazil E-mail: emanueleersilva@gmail.com Brenda Tuany Pacheco Dias

ORCID: https://orcid.org/0000-0002-0272-4534 Universidade Federal do Pará, Brazil E-mail: b.tuanydias@gmail.com

Jéssica Haline Souza dos Reis

ORCID: https://orcid.org/0000-0003-1971-9763 Universidade Federal do Pará, Brazil E-mail: halinereis26@gmail.com

Katiane da Costa Cunha

ORCID: https://orcid.org/0000-0001-5361-5090 Universidade do Estado do Pará, Brazil E-mail: katiane.cunha@uepa.br Aurimery Gomes Chermont ORCID: https://orcid.org/0000-0001-8715-3576 Universidade Federal do Pará, Brazil E-mail: agchermont@gmail.com

\begin{abstract}
Objectives: To determine blood glucose distribution values; to assess the association of admission serum glucose levels with 28-day mortality to the frequency of invasive mechanical ventilation-free days. Design: Retrospective cohort studySetting: Brazilian Amazon Region. Patients: Population $(n=400)$ composed of patients admitted to the pediatric intensive care unit, from January 2016 to December 2017. Exclusion criteria were patients with length of stay of < 24 hours; diabetes mellitus; suspicion or evidence of inborn errors of metabolism; insulin use; palliative care
\end{abstract}


and brain death. Main outcome measures: The patients were divided into 4 groups: 1) serum glucose $<60 \mathrm{mg} / \mathrm{dL} ; 2$ ) control group if serum glucose between $60-126 \mathrm{mg} / \mathrm{dL}$; 3) between $127-150 \mathrm{mg} / \mathrm{dL}$; or 4) if > 150mg/dL. Results: Serum glucose levels frequency were: <60: 43 (11\%); 60-126: 235 (58.7\%); 127-150: 51 (13\%) and > 150: 71 (18\%). Groups 3 and 4 had the highest frequency of external origin, with respectively $24(47.1 \%)$ and $40(56.3 \%)$; the main diagnosis was infection, with $26(51 \%)$ and $50(70.4 \%)$, respectively. Sepsis occurred in $24(47.1 \%)$ and $47(66.2 \%)$ individuals in the groups 3 and 4, respectively, while septic shock was more frequent in the group 4 (46 [4.8\%]). Group 2 had predominance of ventilator-associated pneumonia with $11(36.7 \%)$. The estimate of ventilation-free days in group 4 was 2.84 (SD +/- 0.69; 95\% CI: 1.5-4.2). Conclusion: Hyperglycemia group had a lower frequency of ventilation-free days and higher 28-day mortality.

Keywords: Blood glucose; Mortality; Risk factors; Intensive care units, Pediatric; Hypoglycemia; Hyperglycemia.

\section{Resumo}

Objetivos: Determinar os valores de distribuição da glicose no sangue; Avaliar a associação dos níveis séricos de glicose na admissão com a mortalidade aos 28 dias e a frequência de dias livres de ventilação mecânica invasiva. Delineamento: Estudo de coorte retrospectivo Local: Amazônia Brasileira. Pacientes: População $(n=400)$ composta por pacientes internados em unidade de terapia intensiva pediátrica, no período de janeiro de 2016 a dezembro de 2017. Os critérios de exclusão foram pacientes com internação < 24 horas; Diabetes mellitus; suspeita ou evidência de erros inatos do metabolismo; uso de insulina; cuidados paliativos e morte encefálica. Principais desfechos: os pacientes foram divididos em 4 grupos: 1) glicose sérica $<60 \mathrm{mg} / \mathrm{dl}$; 2) grupo controle se a glicemia sérica estiver entre 60-126 mg / dL; 3) entre 127-150 mg / dL; ou 4) se> $150 \mathrm{mg} / \mathrm{dL}$. Resultados: A frequência dos níveis séricos de glicose foi: <60: 43 (11\%); 60-126: 235 (58,7\%); 127-150: 51 (13\%) e> 150: 71 (18\%). Os grupos 3 e 4 apresentaram a maior frequência de origem externa, com $24(47,1 \%)$ e $40(56,3 \%)$ respectivamente; o diagnóstico principal foi infecção, com $26(51 \%)$ e 50 (70,4\%), respectivamente. A sepse ocorreu em $24(47,1 \%)$ e $47(66,2 \%)$ indivíduos dos grupos 3 e 4, respectivamente, enquanto o choque séptico foi mais frequente no grupo 4 (46 [4,8\%]). O Grupo 2 teve predomínio de pneumonia associada à ventilação mecânica com 11 (36,7\%). A estimativa de dias sem ventilação no grupo 4 foi de 2,84 (DP +/- 0,69, IC 95\%: 1,5-4,2). Conclusão: o grupo hiperglicêmico apresentou menor frequência de dias sem ventilação e maior mortalidade aos 28 dias.

Palavras-chave: Glicemia; Mortalidade; Fatores de risco; Unidades de terapia intensiva pediátrica; Hipoglicemia; Hiperglicemia.

\section{Resumen}

Objetivos: Determinar los valores de distribución de glucosa en sangre; evaluar la asociación de los niveles de glucosa sérica al ingreso con la mortalidad a los 28 días con la frecuencia de días libres de ventilación mecánica invasiva. Diseño: Estudio de cohorte retrospectivo Lugar: Región Amazónica brasileña. Pacientes: Población $(n=400)$ compuesta por pacientes ingresados en la unidad de cuidados intensivos pediátricos, de enero de 2016 a diciembre de 2017. Los criterios de exclusión fueron pacientes con estadía < 24 horas; diabetes mellitus; sospecha o evidencia de errores innatos del metabolismo; uso de insulina; cuidados paliativos y muerte cerebral. Principales medidas de resultado: Los pacientes se dividieron en 4 grupos: 1) glucosa sérica $<60 \mathrm{mg} / \mathrm{dl}$; 2) grupo de control si la glucosa en suero está entre 60-126 mg / dL; 3) entre 127-150 mg / dL; o 4) si> $150 \mathrm{mg} / \mathrm{dL}$. Resultados: La frecuencia de los niveles de glucosa en suero fue: <60: 43 (11\%); 60-126: 235 (58,7\%); 127-150: 51 (13\%) y> 150: 71 (18\%). Los grupos 3 y 4 tuvieron la mayor frecuencia de origen externo, con $24(47,1 \%)$ y $40(56,3 \%)$ respectivamente; el diagnóstico principal fue infección, con $26(51 \%)$ y 50 (70,4\%), respectivamente. La sepsis ocurrió en $24(47,1 \%)$ y $47(66,2 \%)$ individuos en los grupos 3 y 4 , respectivamente, mientras que el choque séptico fue más frecuente en el grupo 4 (46 [4,8\%]). El grupo 2 tuvo predominio de neumonía asociada a ventilador con 11 (36,7\%). La estimación de días sin ventilación en el grupo 4 fue 2,84 (DE +/- 0,69; IC del 95\%: 1,5-4,2). Conclusión: el grupo de hiperglucemia tuvo una menor frecuencia de días sin ventilación y una mayor mortalidad a los 28 días.

Palabras clave: Glucosa; Mortalidad; Factores de riesgo; Unidades de cuidados intensivos pediátricos; Hipoglucemia; Hiperglucemia.

\section{Introduction}

Severe sepsis and septic shock, resulted from infection, are the main causes of mortality and morbidity among children, despite advances in prevention and treatment (Farrell \& Nadel, 2016) that resulted in a marked reduction in the mortality of cases - especially in developed countries (Garcia et al., 2020).

Glucose homeostasis is altered among children with septic shock, and the systemic inflammation related to such condition results in wide glycemic variation (Güemes et al., 2016; Hartl \& Jauch, 2014; Wanek \& Wolf, 2007). Thus, it is expected of these children to have a higher risk of developing hyperglycemia during metabolic stress, which favors an 
imbalance between the immune and inflammatory responses, evolving with tissue injury and cell death (Baker et al., 2011; Kyle et al., 2010; Lenzen, 2008).

Therefore, hyperglycemia, glycemic variation, and hypoglycemia are related with worse clinical results in children with septic shock, such as longer hospital length of stay, mechanical ventilation duration, and high mortality rates (Bagshaw et al., 2009; Branco et al., 2005; Day et al., 2008; Krinsley et al., 2011; Kyle et al., 2010).

Despite the numerous publications in the literature that evaluate the glycemic level and its association with worse clinical outcomes in pediatric septic shock patients, there are few studies in the theme regarding regions with limited socioeconomic and structural resources (Bagshaw et al., 2009; Krinsley et al., 2011; Kyle et al., 2010), such as the Northern region of Brazil, located in the Brazilian Amazon - that has no studies on this topic so far. Pará state stands out among the Amazon states with such profile; it has 144 municipalities subdivided into microregions and mesoregions, and a vast territorial extension of 1,247,689.76 $\mathrm{km}^{2}$, and demographic density of 1,315.26 inhabitants per $\mathrm{km}^{2}$. In 2018 , it had an estimated population of 8,513,497 inhabitants (IBGE, n.d.; Ministério da Saúde, 2018).

Based on the hypothesis that changes in glucose homeostasis are common in patients with septic shock, the objectives of this study were: (1) to determine the frequency of blood glucose values, concerning to the hyperglycemia and hypoglycemia groups; (2) to evaluate the association of serum glucose admission level, with 28-day mortality as the primary outcome and the frequency of ventilation-free days and disease severity as a secondary outcome in this group.

\section{Materials and Methods}

\section{Study design}

Retrospective cohort observational study (Pereira et al., 2018).

\section{Study population}

The population consisted of all pediatric patients with septic shock (Rigby et al., 2013), admitted to the pediatric intensive care unit of the Santa Casa de Misericórdia do Pará Foundation (FSCMPA-PICU), a maternal and child referral hospital in Pará state, in the period from January 2015 to December 2017. The following were excluded: patients hospitalized for less than 24 hours; diagnosed with diabetes mellitus; with suspicion or evidence of inborn errors of metabolism; insulin use; those in palliative care, and brain death(Güemes et al., 2016).

The FSCMPA-PICU has ten hospital beds and attends children with clinical and non-traumatological diseases, delivered either from the very hospital or from emergency services of the Unified Health System, in addition to wards and surgical sectors of the hospital itself. As it is a humanized PICU, the child responsible remains throughout the entire hospitalization, full time (Pará, n.d.).

\section{Study Variables}

Data were obtained through the unit's data system, for the following variables: name, age, sex, date of admission, date of discharge, hospital record, type of discharge, and diagnosis on admission. After initial screening, a survey and confirmation of the data was obtained by consulting the medical records system used at the FSCMPA-PICU, the Electronic Patient Record (MVPEP $®$, MV, Recife, Brazil), completed by the multidisciplinary team from the unit for all the admitted patients. After compiling the collected data, it was inserted in a previously formulated research protocol, and the analysis was built on a bank and spreadsheets in the Microsoft Office Excel $\circledR^{2} 2016$ program (Microsoft, Washington, USA). 
Age range cutt-off criteria followed the Brazilian Ministry of Heatlh guide, that divides groups into: infants (0 to 1 year and 11 months of age), preschoolers (2 to 5 years and 11 months of age), school-age children (6 to 10 years of age) and adolescents (up to 19 years of age).

All children included in the study had at least one blood glucose value measured in the first 24 hours after admission. In the case of multiple measurements, the closest to the time of admission worst value was selected. Whole blood glucose concentrations were measured from arterial or venous samples using an automatic biomedical blood gas analyzer. The blood glucose concentration was expressed in milligrams per deciliter (mg / dL).

There are no specific criteria for defining hyperglycemia or hypoglycemia among critically ill children. Hyperglycemia was defined as blood glucose level higher than $150 \mathrm{mg} / \mathrm{dL}$, as hypoglycemia was defined as blood glucose level lower than $60 \mathrm{mg} / \mathrm{dL}$. The choice of cut-off values was based on the definitions used by the unit's physicians in clinical practice.

The variables included for analysis were: age; sex; reason for hospitalization (clinical or surgical); primary dysfunction on admission; the presence of comorbidities; admission blood glucose value; primary outcome (mortality within 28 days); secondary outcome (ventilation-free days); Pediatric Risk of Mortality IV (PRISM IV) (Pollack et al., 2016); the presence of Ventilation-Associated Pneumonia (VAP); hemodynamic support (use of vasoactive drugs, insertion of central venous catheter); the need of ventilatory support on admission; corticosteroid (CS) use; the need of nutritional therapy with Parenteral Nutrition (PN); length of stay in the hospital and time on mechanical ventilation.

\section{Statistical analysis}

The numerical data were expressed in absolute values and percentages. After applying the Shapiro-Wilk test, a bivariate analysis between the control group and the other groups was initially carried out to assess the association between the case groups and the clinical and epidemiological variables. After applying the Fisher's Exact test, G-Test and Chi-square, multiple logistic regression analysis was applied due to the groups' low frequency. For the variables selection, variables with $\mathrm{p}<0.05$ in the bivariate analysis were tested in the chosen model. Thus, those considered significant for $\mathrm{p}<0.05$ and with $95 \%$ CI, had Odds Ratio (OR) calculation in this model. Statistical analyzes were performed using the Minitab® 14.0 program (Minitab, LLC, Pennsylvania, USA).

After determining the variables independently related to the outcome and with the established predictive model, the association of death and ventilation-free days predicted probabilities was calculated; for this analysis, it was established up to 28 days of hospitalization.

This research was approved by the Research Ethics Committee of the Santa Casa de Misericórdia do Pará Foundation, in conformity to the requirements established in the Nuremberg Code and the Declaration of Helsinki (Gandevia \& Tovell, 1964; Mainetti, 1947) and was based on the basic principles of bioethics present in Resolution No. 466 / 12 from the National Health Council of Brazil, which provides for research involving human beings, under the opinion number 3.164.138/2019 and Presentation Certificate for Appreciation number 02152818.5.0000.5171.

\section{Results}

There were 458 admissions to the FSCMPA-PICU during the study period, from which 400 (87.4\%) medical records were included in the study. Figure 1 specifies, in a flow chart, the reasons for including and excluding medical records from the research. 
Figure 1 - Flow chart of the criteria for inclusion and exclusion of medical records $(n=400)$.



Source: Authors.

Male children (53.8\%) had the greatest participation, compared to females (46.2\%). Among the patients who developed septic shock, the female population was the majority (54.9\%), however, the variable " Gender" did not present a statistical association with the outcome $(p$-value $=0.021)($ Table 1$)$.

Infants were most of the population (43.5\%), followed by 139 preschoolers $(34.8 \%)$ and 51 school-age children $(12.7 \%)$; only $36(9 \%)$ of the admitted patients were part of the adolescent age range. The variable "Age range" was not statistically significant neither between the groups with septic shock or without septic shock $(p$-value $=0.18)$. (Table 1). 
Table 1 - Sociodemographic characterization of the population according to septic shock status, 2015-2017, Belém, Pará state, Brazil. $(n=400)$.

\begin{tabular}{|c|c|c|c|c|c|c|c|}
\hline \multirow{3}{*}{$\begin{array}{c}\text { Sociodemographic variables } \\
\text { Gender }\end{array}$} & \multicolumn{7}{|c|}{ Septic Shock } \\
\hline & \multicolumn{2}{|c|}{ Without } & \multicolumn{2}{|c|}{ With } & \multicolumn{2}{|c|}{ All patitens } & \multirow[b]{2}{*}{$p$ value } \\
\hline & $\mathrm{n}$ & $\%$ & $\mathrm{~N}$ & $\%$ & $\mathrm{n}$ & $\%$ & \\
\hline Female & 118 & 42,4 & 67 & 54,9 & 185 & 46,2 & $0,021^{\mathrm{a}}$ \\
\hline \multirow[t]{2}{*}{ Male } & 160 & 57,6 & 55 & 45,1 & 215 & 53,8 & \\
\hline & 278 & 100 & 122 & 100 & 400 & 100 & \\
\hline \multicolumn{8}{|l|}{ Age range } \\
\hline Infants & 114 & 41 & 60 & 49,2 & 174 & 43,5 & $0,18^{\mathrm{a}}$ \\
\hline Preschoolers & 106 & 38,1 & 33 & 27 & 139 & 34,8 & \\
\hline School-age children & 33 & 11,9 & 18 & 14,8 & 51 & 12,7 & \\
\hline \multirow[t]{2}{*}{ Adolescents } & 25 & 9 & 11 & 9 & 36 & 9 & \\
\hline & 278 & 100 & 122 & 100 & 400 & 100 & \\
\hline \multicolumn{8}{|l|}{ Reason for hospitalization } \\
\hline Clinical & 204 & 73,4 & 118 & 96,7 & 322 & 80,5 & $<0,0001^{\mathrm{c}}$ \\
\hline \multirow[t]{2}{*}{ Surgical } & 74 & 26,6 & 4 & 3,3 & 78 & 19,5 & \\
\hline & 278 & 100 & 122 & 100 & 400 & 100 & \\
\hline \multicolumn{8}{|l|}{ Origin } \\
\hline Ward & 124 & 44,6 & 49 & 40,2 & 173 & 43,2 & \\
\hline External & 78 & 28 & 66 & 54,1 & 144 & 36 & $<0,0001^{\mathrm{c}}$ \\
\hline Neonatology & 56 & 20,2 & 3 & 2,5 & 59 & 14,8 & \\
\hline \multirow[t]{2}{*}{ Ambulatory } & 20 & 7,2 & 4 & 3,2 & 24 & 6 & \\
\hline & 278 & 100 & 122 & 100 & 400 & 100 & \\
\hline \multicolumn{8}{|l|}{ Comorbidity } \\
\hline Present & 86 & 30,9 & 87 & 71,3 & 173 & 43,3 & $<0,0001^{\mathrm{a}}$ \\
\hline \multirow[t]{2}{*}{ Absent } & 192 & 69,1 & 35 & 28,7 & 227 & 56,7 & \\
\hline & 278 & 100 & 122 & 100 & 400 & 100 & \\
\hline \multicolumn{8}{|l|}{ Avarage length of stay in days } \\
\hline Up to 5 & 97 & 34,9 & 33 & 27 & 130 & 32,5 & $0,08^{a}$ \\
\hline 6 to 10 & 57 & 20,5 & 33 & 27 & 90 & 22,5 & \\
\hline 11 to 15 & 27 & 9,7 & 24 & 19,7 & 51 & 12,8 & \\
\hline \multirow[t]{2}{*}{$>15$} & 97 & 34,9 & 32 & 26,3 & 129 & 32,2 & \\
\hline & 278 & 100 & 122 & 100 & 400 & 100 & \\
\hline
\end{tabular}

${ }^{\mathrm{a}}$ Pearson chisquare test; ${ }^{\mathrm{b}} \mathrm{G}$ Wilks test; ${ }^{\mathrm{c}}$ Fisher exact test. Source: The authors.

Regarding the average PICU length of stay, most patients $(32.5 \%)$ stayed for five days or less. On the other hand, $32.2 \%$ of the patients included in the study remained for over 15 days. The average PICU length of stay was not statistically associated with the outcome $(p$-value $=0.08)($ Table 1$)$.

Invasive Mechanical Ventilation (IMV) was necessary for most of the sample, accounting for 340 (85\%) of the patients, even more important in the group of 177 who evolved with septic shock (95.9\%). As for the length of stay, a total of 
199 (49.8\%) patients stayed at IMV for up to 3 days, of which 55 had septic shock. Both “ IMV on admission” and “ time on IMV" were statistically associated with the outcome ( $p$-value <0.0001) (Table 2).

Table 2 - Clinical characteristics of the population according to the septic shock status, 2015-2017, Belém, Pará state, Brazil. $(n=400)$.

\begin{tabular}{|c|c|c|c|c|c|c|c|}
\hline \multirow{3}{*}{$\begin{array}{c}\text { Variables } \\
\text { IMV on admission }\end{array}$} & \multicolumn{7}{|c|}{ Septic Shock } \\
\hline & \multicolumn{2}{|c|}{ Absent } & \multicolumn{2}{|c|}{ Present } & \multicolumn{2}{|c|}{ Sample } & \multirow[b]{2}{*}{ valor $p$} \\
\hline & $\mathbf{N}$ & $\%$ & $\mathbf{n}$ & $\%$ & $\mathbf{n}$ & $\%$ & \\
\hline Yes & 223 & 80,3 & 117 & 95,9 & 340 & 85 & $<0,0001^{\mathrm{b}}$ \\
\hline \multirow{2}{*}{ No } & 55 & 19,7 & 5 & 4,1 & 60 & 15 & \\
\hline & 278 & 200 & 122 & 200 & 400 & 200 & \\
\hline \multicolumn{8}{|l|}{ Time on IMV } \\
\hline Up to 3 days & 144 & 51,8 & 55 & 45,1 & 199 & 49,8 & $<0,0001^{\mathrm{c}}$ \\
\hline 3 to 7 days & 41 & 14,7 & 35 & 28,7 & 76 & 19 & \\
\hline 8 to 10 days & 31 & 11,1 & 26 & 21,3 & 57 & 14,2 & \\
\hline 11 to 14 days & 8 & 2,9 & 1 & 0,8 & 9 & 2,3 & \\
\hline \multirow[t]{2}{*}{$>15$ days } & 54 & 19,5 & 5 & 4,1 & 59 & 14,7 & \\
\hline & 278 & 100 & 122 & 100 & 400 & 100 & \\
\hline \multicolumn{8}{|l|}{ Vasoactive Support } \\
\hline Yes & 80 & 28,8 & 121 & 99,2 & 201 & 50,3 & $<0,0001^{\mathrm{c}}$ \\
\hline \multirow[t]{2}{*}{ No } & 198 & 71,2 & 1 & 0,8 & 199 & 49,7 & \\
\hline & 278 & 100 & 122 & 100 & 400 & 100 & \\
\hline \multicolumn{8}{|l|}{ CVC use } \\
\hline Yes & 225 & 80,9 & 120 & 98,4 & 345 & 86,3 & $<0,0001^{\mathrm{c}}$ \\
\hline \multirow[t]{2}{*}{ No } & 53 & 19,1 & 2 & 1,6 & 55 & 13,7 & \\
\hline & 278 & 100 & 122 & 100 & 400 & 100 & \\
\hline \multicolumn{8}{|c|}{ Nutritional support therapy with PN } \\
\hline Yes & 19 & 6,8 & 19 & 15,6 & 38 & 9,5 & $0,006^{\mathrm{a}}$ \\
\hline \multirow[t]{2}{*}{ No } & 259 & 93,2 & 103 & 84,4 & 362 & 90,5 & \\
\hline & 278 & 100 & 122 & 100 & 400 & 100 & \\
\hline \multicolumn{8}{|l|}{ CS use } \\
\hline Yes & 114 & 41 & 89 & 72,9 & 203 & 50,8 & $<0,0001^{a}$ \\
\hline \multirow[t]{2}{*}{ No } & 164 & 59 & 33 & 27,1 & 197 & 49,2 & \\
\hline & 278 & 100 & 122 & 100 & 400 & 100 & \\
\hline \multicolumn{8}{|l|}{ PRISM IV } \\
\hline Up to 10 & 133 & 47,8 & 14 & 11,4 & 147 & 36,8 & \\
\hline 11 to 20 & 110 & 39,7 & 50 & 41 & 160 & 40 & $<0,0001^{\mathrm{a}}$ \\
\hline 21 to 30 & 16 & 5,7 & 29 & 23,8 & 45 & 11,2 & \\
\hline \multirow[t]{2}{*}{$>30$} & 19 & 6,8 & 29 & 23,8 & 48 & 12 & \\
\hline & 278 & 100 & 122 & 100 & 400 & 100 & \\
\hline
\end{tabular}

Admission serum glucose (mg/dL) 


$\begin{array}{cccccccc}<60 & 40 & 14,4 & 3 & 2,5 & 43 & 10,7 & \\ 60-126 & 183 & 65,8 & 52 & 42,6 & 235 & 58,8 & \\ 127-150 & 30 & 10,8 & 21 & 17,2 & 51 & 12,7 & \\ >150 & 25 & 9 & 46 & 37,7 & 71 & 17,8 & <0,0001^{c} \\ & 278 & 100 & 122 & 100 & 400 & 100 & \\ \text { VAP } & & & & & & & \\ \text { Yes } & 46 & 16,5 & 13 & 10,7 & 59 & 14,7 & 0,13^{\mathrm{a}} \\ \text { No } & 232 & 83,5 & 109 & 89,3 & 341 & 85,3 & \\ & 278 & 100 & 122 & 100 & 400 & 100 & \\ \text { IMV-free days } & & & & & & & \\ \text { Over 3 } & 183 & 82,1 & 95 & 81,2 & 278 & 81,8 & 0,01^{\mathrm{a}} \\ \text { Under 3 } & 40 & 17,9 & 22 & 18,8 & 62 & 18,2 & \\ & 223 & 100 & 117 & 100 & 340 & 100 & \\ \text { 28-day mortality } & & & & & & & \\ \text { Yes } & 23 & 8,3 & 50 & 41 & 73 & 18,2 & <0,0001^{\mathrm{a}} \\ \text { No } & 255 & 91,7 & 72 & 59 & 327 & 81,8 & \\ & 278 & 100 & 122 & 100 & 400 & 100 & \end{array}$

a) IMV: Invasive Mechanical Ventilation; b) CVC: Central Venous Catheter; c) Parenteral Nutrition; d) CS: Corticosteroid; e) PRISM IV: Pediatric Risk of Mortality; f) VAP: Ventilation Associated Pneumonia.

${ }^{\mathrm{a}}$ Pearson chisquare test; ${ }^{\mathrm{b}} \mathrm{G}$ Wilks test; ${ }^{\mathrm{c}}$ Fisher exact test.

Source: Authors.

Over half of all patients (201 - 50.3\%), received vasoactive support, and in the group with present septic shock, vasoactive support accounted for $99.2 \%$ of the patients. The CVC was used in most of the sample, accounting for 345 (86.3\%) patients. Both variables were statistically associated with the outcome ( $p$-value $<0.0001$ ) (Table 2).

The PRISM IV index had most frequent score range from 0 to 10, accounting for 147 (36.8\%) individuals. In the group of patients who had septic shock, the most frequent score was 11 to 20 , which added up to 50 (41\%) patients. It was statistically associated with the outcome (P-value <0.0001) (Table 2).

The blood glucose on admission had 117mg / dL avarage, with a 108 median, SD +/- 49.8, IIQ: 93-137, ranging from 20 to $490 \mathrm{mg} / \mathrm{dL}$. In the septic shock group, it had higher average, with 139mg / dL, SD + / -48.3, median 132.5, IIQ: 103-168 with a range from 43 to 482 , compared to the group without septic shock with a mean of $106.7 \mathrm{mg} / \mathrm{dL}$, median of 102, IIQ: 90-117 and variation from 20 to 490., DP+/-49,8, IIQ: 93-137.

The frequency of serum glucose levels were: 40 cases (14.4\%) with blood glucose $<60 \mathrm{mg} / \mathrm{dL}$, and 25 cases (9\%) above $150 \mathrm{mg} / \mathrm{dL}$, in patients without septic shock. The group with septic shock had frequency of hypoglycemia and hyperglycemia of $3(2.5 \%)$ and $46(37.7 \%)$ cases, respectively. Blood glucose at admission was associated with the outcome (P-value <0.0001) (Table 2).

As for the 28-day mortality, it was present in $73(18.2 \%)$ of the patients, and in the group who had septic shock, it was present in $50(41 \%)$ of the patients. 28-day mortality was associated with progression to septic shock (P-value <0.0001) (Table 2).

Table 3 shows that the chance of the disease to present severity is $5.1 \%$ in relation to "Hyperglycemia and septic shock" . While " Hypoglycemia and septic shock" presented zero chance in view of the disease severity. 
Table 3 - Effects of hyperglycemia and hypoglycemia on morbidity and mortality according to the state of septic shock.

\begin{tabular}{lccc}
\hline Serum glucose on admission & Disease severity & IMV-free days & 28-day mortality \\
\hline & OR(CI95\%) & OR(CI95\%) & OR(CI95\%) \\
\cline { 2 - 4 } $\begin{array}{l}\text { Hyperglycemia and septic } \\
\text { shock }\end{array}$ & $5,1(2,8-10,9)^{\mathrm{a}}$ & $1,8(1-3,2)^{\mathrm{a}}$ & $0,2(0,1-0,4)^{\mathrm{a}}$ \\
& & $0,8(0,5-12)^{\mathrm{c}}$ & $1,3(0,1-16,7)^{\mathrm{b}}$ \\
$\begin{array}{l}\text { Hypoglycemia and septic } \\
\text { shock }\end{array}$ & ----- & $0,7(0,06-92)^{\mathrm{c}}$ & $1,6(0,5-51)^{\mathrm{b}}$ \\
\hline
\end{tabular}

a) IMV: Invasive Mechanical Ventilation.

PRISMIV, Risk Pediatric of Mortality $\geq$ third quartile; Prolonged ventilation: ventilator-free days <3 days (third quartile); OR: Odds Ratio; CI: confidence interval

${ }^{a}$ Cochran-Mantel-Haenszel analysis: there was significant association between the 2 variables of interest when controlled for septic shock, only for hyperglicemia, with respective $p$ values: $<0,0001 ; 0,037$ and $<0,0001$.

${ }^{\mathrm{b}}$ Multiple logistic regression analysis adjusted by control group; there was significant association for Mortality with hyperglicemia and hipoglicemia, with respective $p$ values: 0,039 and 0,05

${ }^{\mathrm{c}}$ Multiple logistic regression analysis adjusted by control group; there was significant association for ventilator free days with hyperglicemia and hipoglicemia, with respective $p$ values: 0,019 and 0,016

Source: Authors.

Regarding the item “IMV-free days", the Cochran-Mantel-Haenszel analysis associated 2 variables of interest, which when controlled for septic shock, only for hyperglycemia, obtained $1.8 \%$ chances of patients with " Hyperglycemia and Septic Shock" to need mechanical ventilation. As for the multiple logistic regression analysis adjusted by the control group, there was a significant association of ventilation-free days with hyperglycemia and hypoglycemia. When compared, the "hyperglycemia and septic shock" group had a $0.8 \%$ chance of remaining free of ventilation, while patients in the "hypoglycemia and septic shock" group had a $0.7 \%$ chance (Table 3 ).

Regarding the variable "28-day mortality", in relation to the "Hyperglycemia and septic shock" group, also analyzed from the Cochran-Mantel-Haenszel perspective, $0.2 \%$ of these patients died within 28 days. The multiple logistic regression analysis adjusted by the control group, presented for the association of Mortality with hyperglycemia and hypoglycemia, showed that patients with hyperglycemia had a $1.3 \%$ chance of progressing to death in this period. On the other hand, the chance of a patient with hypoglycemia is $1.6 \%$. There were more deaths in this condition than in relation to hyperglycemia (Table 3). 
Figure 2 - Association of blood gluose leves with ventilator free days and mortality.

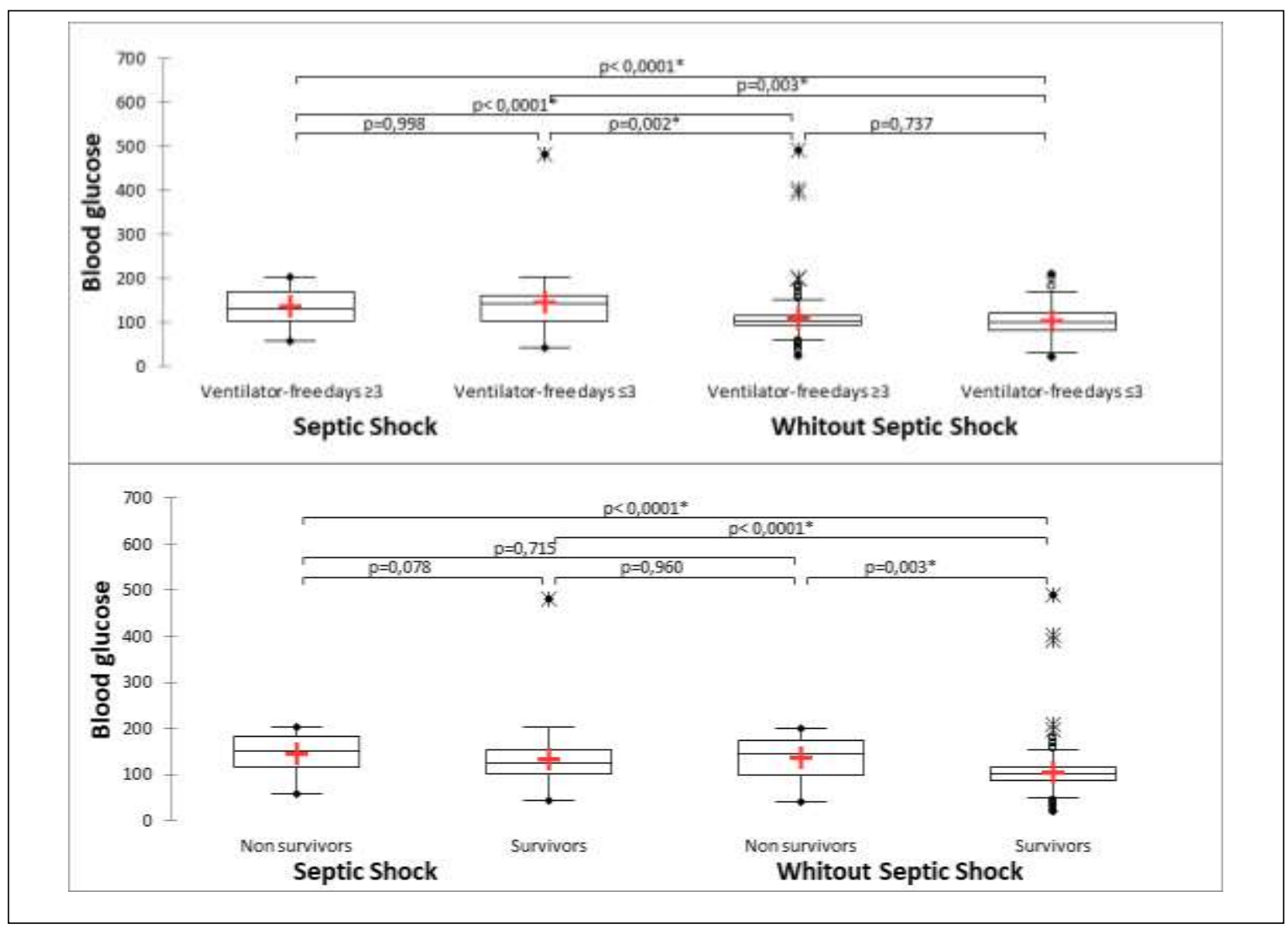

*Comparison of blood glucose levels on mg/dL (Kruskal-Wallis test and Multiple pairwise comparisons using the Steel-Dwass-CritchlowFligner procedure/Two-tailed tests) acording to Septic Shock Status effect on Mortality and ventilator free days. Source: Authors.

Among the patients with septic shock, the higher the glucose levels, higher the mortality. The patients who did not have septic shock and evolved with death had, for the most part, higher glucose levels, while survivors in the same condition had a lower glucose rate (Figure 2).

\section{Discussion}

The pathophysiology of septic shock involves circulatory, cellular, and metabolic responses (Rhodes et al., 2017). Metabolic stress incurs in an increase in proinflammatory cytokines and hyperglycemic hormones (such as growth hormone), and a reduction in the insulin-like growth factor, which leads to an increase in the inflammatory response in the tissues and an imbalance of the immune response (Aleman \& Guerrero, 2018; Singer et al., 2016).

Therefore, the glycemic level in critically ill patients with sepsis and septic shock is correlated with worse outcomes, such as multiple organ dysfunction, longer ventilation time, and death; Van Vught et al (2016), Chan et al (2016), and Wang et al (2019) found an association between high blood glucose levels, worse clinical response and increased risk of mortality (Singer et al., 2016; Van Vught et al., 2016; Wang et al., 2019), which corroborates the findings of the present study.

Glycemic variation is a severity marker in critically ill patients, as observed in this study and alluded to by Toro-Polo et al (2018), Okazaki et al (2018), and Kim et al (2019) (Kim et al., 2019; Okazaki et al., 2018; Toro-Polo et al., 2018). For this reason and since it is a low-cost method, several measurements are required during hospitalization, facilitating the continuous assessment of patients in intensive care units (Kim et al., 2019; Okazaki et al., 2018; Toro-Polo et al., 2018). 
In this context, El-Sherbini, Marzouk, El-Sayed, and Hosam-ElDin (2018) (El-Sherbini et al., 2018; E. Faustino et al., 2019) related glycemic values equal to or greater than 180mg / dL to worse clinical outcomes; Faustino \& Apkon (2005) (E. V. Faustino \& Apkon, 2005) found an increased risk of mortality and a longer stay in intensive care when glucose levels exceeded $150 \mathrm{mg} / \mathrm{dL}$. These findings are similar to the present study, in which hyperglycemia and septic shock were statistically associated with the severity of the disease, with 28-day mortality, and with IMV-free days.

On the other hand, Faustino et al (2019) (El-Sherbini et al., 2018; E. Faustino et al., 2019) associated blood glucose levels below 40mg / dL with worse short-term results, as well as Toro-Polo et al (Kim et al., 2019; Okazaki et al., 2018; ToroPolo et al., 2018), who registered a higher risk of death on discharge from PICU patients in Peru $(\mathrm{N}=522)$. In the study carried out at FSCMPA, hypoglycemia was also associated with 28-day mortality, as well as with IMV-free days, but it was more common in patients without shock septic.

Among the key factors that can influence the prognosis of patients with septic shock are the nature of the infection, the presence of underlying diseases, and immunosuppression (Rhodes et al., 2017). However, in regard to the pediatric population hospitalized in the intensive care unit, there are few studies available demonstrating the association between glycemic values and prognosis, even in countries with high socioeconomic and intellectual levels.

This study demonstrated that patients in the hyperglycemic group had a higher incidence of nosocomial infections, mechanical ventilation duration, and death rate. Pulmonary disease in patients with sepsis emphasizes the need for ventilatory support that minimizes lung damage, that is usually elevated the longer the need for mechanical ventilation (Nieman et al., 2017; Zampieri \& Mazza, 2017). As for mortality due to septic shock, it can result from late diagnosis and late treatment scenario in which developing countries lead, given the scarcity of resources (de Souza \& Machado, 2019).

The need for CVC can be a gateway for opportunistic pathogens such as Candida, especially in cases of longer length of stay (Rhodes et al., 2017). Furthermore, corticosteroids prescription for the management of sepsis and septic shock is controversial; despite being widely used as an adjuvant to reduce state duration, mortality, as well as to prevent its transition to multiple organ dysfunction (Annane et al., 2018; Darmaros et al., 2016), its benefits may depend on variables such as initial risk mortality or may be absent, as demonstrated by Atkinson et al (2014) (Atkinson et al., 2014).

The relevance of this study is in highlighting the data from FSCMPA-PICU and use the glycemic level as a marker of severity, predictor of prognosis, and mortality in patients with sepsis / septic shock. The use of insulin is indicated in order to prioritize the adequate control of serum glucose, however, studies have demonstrated an increased risk of hypoglycemia, and should be used with discretion (Agus et al., 2017; E. Faustino et al., 2019). The study's limitations are related to the retrospective design and its realization in a single-center, with a limited number of patients.

\section{Conclusion}

The frequency of hypoglycemia was higher in patients without septic shock, while hyperglycemia was higher in those who progressed to such condition. The association between high serum glucose level and septic shock denoted a worse overall outcome for the group, to 28-day mortality - that was higher in this group - and the time free from invasive mechanical ventilation - which was lower - both.

Taking into account the lack of resources present in most of the Brazilian Amazon region and the socioeconomic and cultural disparities of the population, it is extremely important to use low-cost and easily accessible methods to identify patients at greatest risks. It must take in consideration the unfavorable clinical conditions for which patients are admitted to the PICU, so it can be used to obtain better results in scores of severity, mortality rate, survival / quality of life and show the minimum of sequelae - mainly neurological - as possible. For future research, it is suggested that the investigation of factors 
that may predispose children from the Brazilian Amazon to unfavorable outcomes, raised by this article, in addition to the analysis of which pathogens are more related to sepsis in this population.

\section{Acknowledgments:}

Our deepest gratitude to the managers of the Santa Casa de Misericórdia do Pará Foundation and members of the pediatric intensive care unit Dr. Sidney Barbosa team, who allowed and helped the data collection and thus made possible the making of this manuscript: Manoel Eduardo Amoras Gonçalves - President of FSCMPA; Rosane Marques Rosado GomesAdministrative and Financial Director of FSCMPA; Lourival Rodrigues Marsola-FSCMPA Technical Assistance Director; Cinthya Francinete Pereira Pires -FSCMPA Operational Technical Assistance Directorate; Pilar Maria de Oliveira MoraesDirectorate of Education and Research of FSCMPA.

\section{References}

Agus, M. S. D., Wypij, D., Hirshberg, E. L., Srinivasan, V., Faustino, E. V., Luckett, P. M., Alexander, J. L., Asaro, L. A., Curley, M. A. Q., Steil, G. M., \& Nadkarni, V. M. (2017). Tight glycemic control in critically Ill children. New England Journal of Medicine, 376(8), 729-741. https://doi.org/10.1056/NEJMoa1612348

Aleman, L., \& Guerrero, J. (2018). Hiperglicemia por sepsis: del mecanismo a la clínica. Revista Médica de Chile, 146(4), 502-510. https://doi.org/10.4067/s0034-98872018000400502

Annane, D., Renault, A., Brun-Buisson, C., Megarbane, B., Quenot, J. P., Siami, S., Cariou, A., Forceville, X., Schwebel, C., Martin, C., Timsit, J. F., Misset, B., Ali Benali, M., Colin, G., Souweine, B., Asehnoune, K., Mercier, E., Chimot, L., Charpentier, C., \& Bellissant, E. (2018). Hydrocortisone plus fludrocortisone for adults with septic shock. New England Journal of Medicine, 378(9), 809- 818. https://doi.org/10.1056/NEJMoa1705716

Atkinson, S. J., Cvijanovich, N. Z., Thomas, N. J., Allen, G. L., Anas, N., Bigham, M. T., Hall, M., Freishtat, R. J., Sen, A., Meyer, K., Checchia, P. A., Shanley, T. P., Nowak, J., Quasney, M., Weiss, S. L., Banschbach, S., Beckman, E., Howard, K., Frank, E., \& Wong, H. R. (2014). Corticosteroids and pediatric septic shock outcomes: A risk stratified analysis. PLOS ONE, 9(11), 7- 13. https://doi.org/10.1371/journal.pone.0112702

Bagshaw, S. M., Bellomo, R., Jacka, M. J., Egi, M., Hart, G. K., \& George, C. (2009). The impact of early hypoglycemia and blood glucose variability on outcome in critical illness. Critical Care. https://doi.org/10.1186/cc7921

Baker, R. G., Hayden, M. S., \& Ghosh, S. (2011). NF-kB, inflammation, and metabolic disease. In Cell Metabolism. https://doi.org/10.1016/ j.cmet.2010.12.008

Branco, R. G., Garcia, P. C. R., Piva, J. P., Casartelli, C. H., Seibel, V., \& Tasker, R. C. (2005). Glucose level and risk of mortality in pediatric septic shock. Pediatric Critical Care Medicine. https://doi.org/10.1097/01.PCC.0000161284.96739.3 ${ }^{\mathrm{a}}$

Darmaros, L. F., Delgado, A. F., \& Carvalho, W. B. (2016). Corticosteroids in septic shock: What should the decision in pediatrics be? Revista Da Associacao Medica Brasileira, 62(6), 482- 484. https://doi.org/10.1590/1806-9282.62.06.482

Day, K. M., Haub, N., Betts, H., \& Inwald, D. P. (2008). Hyperglycemia is associated with morbidity in critically ill children with meningococcal sepsis. Pediatric Critical Care Medicine. https://doi.org/10.1097/PCC.0b013e31818d350b

de Souza, D., \& Machado, F. (2019). Epidemiology of Pediatric Septic Shock. Journal of Pediatric Intensive Care, 08(01), 003-010. https://doi.org/10.1055/s-0038-1676634

El-Sherbini, S. A., Marzouk, H., El-Sayed, R., \& Hosam-ElDin, S. (2018). Etiology of hyperglycemia in critically ill children and the impact of organ dysfunction. Revista Brasileira de Terapia Intensiva, 30(3), 286- 293. https://doi.org/10.5935/0103-507X.20180051

Farrell, D., \& Nadel, S. (2016). What' s New in Paediatric Sepsis. Current Pediatrics Reports. https://doi.org/10.1007/s40124-016-0093-4

Faustino, E., Hirshberg, E., Asaro, L., Biagas, K., Pinto, N., Srinivasan, V., Bagdure, D., Steil, G., Coughlin-Wells, K., Wypij, D., Nadkarni, V., \& Agus, M. (2019). Short-Term Adverse Outcomes Associated with Hypoglycemia in Critically Ill Children. Critical Care Medicine, 47(5), 706-714. https://doi.org/10.1097/CCM.0000000000003699

Faustino, E. V., \& Apkon, M. (2005). Persistent hyperglycemia in critically ill children. Journal of Pediatrics, 146(1), 30-34. https://doi.org/10.101 6/j.jpeds.2004.08.076

Gandevia, B., \& Tovell, A. (1964). DECLARATION OF HELSINKI. The Medical Journal of Australia. https://doi.org/10.5694/j.1326-5377.1964.tb117959.x

Garcia, P. C. R., Tonial, C. T., \& Piva, J. P. (2020). Septic shock in pediatrics: the state-of-the-art. Jornal de Pediatria (Versão Em Português), 96, 87-98. https://doi.org/10.1016/j.jpedp.2019.10.007

Güemes, M., Rahman, S. A., \& Hussain, K. (2016). What is a normal blood glucose? In Archives of Disease in Childhood. https://doi.org/10.1136/archdischild-2015-308336 
Hartl, W. H., \& Jauch, K. W. (2014). Metabolic self-destruction in critically ill patients: Origins, mechanisms and therapeutic principles. In Nutrition. https://doi.org/10.1016/j.nut.2013.07.019

IBGE (2020). Pará| Cidades e Estados | from https://www.ibge.gov.br/cidades-e-estados/pa.html?

Kim, S., Na, S. J., Park, T. K., Lee, J. M., Song, Y. Bin, Choi, J. O., Hahn, J. Y., Choi, J. H., Choi, S. H., Gwon, H. C., Chung, C. R., Jeon, K., Suh, G. Y., \& Yang, J. H. (2019). Prognostic value of admission blood glucose level in critically ill patients admitted to cardiac intensive care unit according to the presence or absence of diabetes mellitus. Journal of Korean Medical Science, 34(9), 1- 9. https://doi.org/10.3346/jkms.2019.34.e70

Krinsley, J. S., Schultz, M. J., Spronk, P. E., Harmsen, R. E., van Braam Houckgeest, F., van der Sluijs, J. P., Mélot, C., \& Preiser, J. C. (2011). Mild hypoglycemia is independently associated with increased mortality in the critically ill. Critical Care. https://doi.org/10.1186/cc10322

Kyle, U. G., Coss Bu, J. A., Kennedy, C. E., \& Jefferson, L. S. (2010). Organ dysfunction is associated with hyperglycemia in critically ill children. Intensive Care Medicine. https://doi.org/10.1007/s00134-009-1703-1

Lenzen, S. (2008). Oxidative stress: The vulnerable $\beta$-cell. Biochemical Society Transactions, 36(3), 343-347. https://doi.org/10.1042/BST0360343

Mainetti, J. A. (1947). Código De Núremberg. Etica Médica.

Ministério da Saúde. (2018). Situação epidemiológica e estratégias de prevenção, controle e eliminação das doenças tropicais negligenciadas no Brasil, 1995 a 2016. Boletim Epidemiológico Da Secretaria de Vigilância Em Saúde, 49, 1- 15.

Nieman, G. F., Satalin, J., Andrews, P., Aiash, H., Habashi, N. M., \& Gatto, L. A. (2017). Personalizing mechanical ventilation according to physiologic parameters to stabilize alveoli and minimize ventilator induced lung injury (VILI). Intensive Care Medicine Experimental, 5(1), 1-21. https://doi.org/10.1186/s40635-017-0121-x

Okazaki, T., Hifumi, T., Kawakita, K., Shishido, H., Ogawa, D., Okauchi, M., Shindo, A., Kawanishi, M., Tamiya, T., \& Kuroda, Y. (2018). Blood Glucose Variability: A Strong Independent Predictor of Neurological Outcomes in Aneurysmal Subarachnoid Hemorrhage. Journal of Intensive Care Medicine, 33(3), 189- 195. https://doi.org/10.1177/0885066616669328

Pará, F. S. C. de M. do. (2020.). Humanização - Santa Casa do Pará. Retrieved from https://santacasa.pa.gov.br/humanizacao/

Pereira, A. S., Shitsuka, D. M., Parreira, F. J., \& Shitsuka, R. (2018). Metodologia da Pesquisa Científica. In Núcleo de Tecnologia Educacional da Universidade de Santa Maria. https://repositorio.ufsm.br/bitstream/handle/1/15824/Lic_Computacao_Metodologia-Pesquisa-Cientifica.pdf?sequence=1. Acesso em: 28 março 2020.

Pollack, M. M., Holubkov, R., Funai, T., Dean, J. M., Berger, J. T., Wessel, D. L., Meert, K., Berg, R. A., Newth, C. J. L., Harrison, R. E., Carcillo, J., Dalton, H., Shanley, T., Jenkins, T. L., Tamburro, R., \& Nicholson, C. (2016). The Pediatric Risk of Mortality Score: Update 2015. Pediatric Critical Care Medicine, 17(1), 2- 9. https://doi.org/10.1097/PCC.0000000000000558

Rhodes, A., Evans, L. E., Alhazzani, W., Levy, M. M., Antonelli, M., Ferrer, R., Kumar, A., Sevransky, J. E., Sprung, C. L., Nunnally, M. E., Rochwerg, B., Rubenfeld, G. D., Angus, D. C., Annane, D., Beale, R. J., Bellinghan, G. J., Bernard, G. R., Chiche, J. D., Coopersmith, C., \& Dellinger, R. P. (2017). Surviving Sepsis Campaign: International Guidelines for Management of Sepsis and Septic Shock: 2016. In Intensive Care Medicine (Vol. 43, Issue 3). Springer Berlin Heidelberg. https://doi.org/10.1007/s00134-017-4683-6

Rigby, M., Maher, K., Preissig, C., Nitu, M., Rider, C., Rotta, A., \& Leong, T. (2013). The PedIETrol Trial A 2-center trial of glycemic control in pediatric critical illness. Critical Care Medicine, 41, A249. https://doi.org/10.1097/01.ccm.0000440230.74857.4f

Singer, M., Deutschman, C. S., Seymour, C., Shankar-Hari, M., Annane, D., Bauer, M., Bellomo, R., Bernard, G. R., Chiche, J. D., Coopersmith, C. M., Hotchkiss, R. S., Levy, M. M., Marshall, J. C., Martin, G. S., Opal, S. M., Rubenfeld, G. D., Poll, T. Der, Vincent, J. L., \& Angus, D. C. (2016). The third international consensus definitions for sepsis and septic shock (sepsis-3). JAMA - Journal of the American Medical Association, 315(8), 801-810. https://doi.org/10.1001/jama.2016.0287

Toro-Polo, L. M., Ortiz-Lozada, R. Y., Chang-Grozo, S. L., Hernandez, A. V., Escalante-Kanashiro, R., \& Solari-Zerpa, L. (2018). Glycemia upon admission and mortality in a pediatric intensive care unit. Revista Brasileira de Terapia Intensiva, 30(4), 471- 478. https://doi.org/10.5935/0103-507X.20180068

Van Vught, L. A., Wiewel, M. A., Klein Klouwenberg, P. M. C., Hoogendijk, A. J., Scicluna, B. P., Ong, D. S. Y., Cremer, O. L., Horn, J., Bonten, M. M. J., Schultz, M. J., \& Van Der Poll, T. (2016). Admission hyperglycemia in critically ill sepsis patients: Association with outcome and host response. Critical Care Medicine, 44(7), 1338- 1346. https://doi.org/10.1097/CCM.0000000000001650

Wanek, S., \& Wolf, S. E. (2007). Metabolic response to injury and role of anabolic hormones. In Current Opinion in Clinical Nutrition and Metabolic Care. https://doi.org/10.1097/MCO.0b013e3280f31b17

Wang, W., Chen, W., Liu, Y., Li, L., Li, S., Tan, J., \& Sun, X. (2019). Blood Glucose Levels and Mortality in Patients With Sepsis: Dose- Response Analysis of Observational Studies. Journal of Intensive Care Medicine. https://doi.org/10.1177/0885066619889322

Zampieri, F. G., \& Mazza, B. (2017). Mechanical ventilation in sepsis: A reappraisal. Shock, 47(8), 41-46. https://doi.org/10.1097/SHK.0000000000000702 